International Journal of Linguistics, Literature and Translation (IJLLT)

ISSN: 2617-0299 (Online); ISSN: 2708-0099 (Print)

DOI: $10.32996 / \mathrm{jjllt}$

Journal Homepage: www.al-kindipublisher.com/index.php/ijllt

\title{
A Socio-Pragmatic Analysis of the Impact of Impoliteness and Aggressive Language in Violent Online Games on the Players
}

Fatima Abdul Ghany Idrees

Assistant Instructor, General Directorate for Education of Diyala, Iraq

Corresponding Author: Fatima Abdul Ghany Idrees, E-mail: alsaeedyfatima1985@gmail.com

\section{ARTICLE INFORMATION}

Received: October 02, 2020

Accepted: November 14, 2020

Volume: 3

Issue: 11

DOI: $10.32996 /$ ijllt.2020.3.11.20

\section{KEYWORDS}

Impoliteness expressions, Response types, Impoliteness reasons

\section{ABSTRACT}

This study attempted to discover and analyse the impact of violent online games on the players' language and behavior as well as how these expressions might harm, intimidate, and damage others' face. It is worth mentioning that online games become the young's playground where they interact with others and may adopt a certain type of language and behavior. As players engage in a competitive fight of characters, they use certain communicative styles to express their feelings and emotions, including impolite expressions. Hence, this paper looked into these expressions, their responses to those expressions, and the reasons behind them. In addition, this study identified whether there is any impact in choosing these impolite expressions. Moreover, these violent gaming can provide a good field of investigation because impoliteness is widely occurring in such situations, through which people from various cultures, ages and genders come in contact to fight each other, be uncivil, and criticize and damage the other's face. Moreover, these games may even encourage certain harmful impolite terminology and aggressive behavior to inter the players 'repertoire and become the language of everyday use. In gathering the data, impolite expressions were collected by participating in some battles involving abusive and impolite words. Based on the results obtained, the study reached some conclusions that Culpeper's (2005) and Spencer-Oatey's (2002 and 2005) models are applicable in the context of violent online games. There is a big tendency that young people adopt and use various impolite expressions according to their gender and their relations for many reasons. In addition, it is widely recognized that most players have limited politeness competence and directly reply to others' impolite language with hostility. Finally yet importantly, positive impoliteness strategies are used more than the other models, whereas quality of face was the most damaged one in Spencer-Oatey model.

\section{Introduction}

The human being is arguably a volatile creature; thus, institutions must invest to develop the human mind. Specifically, parents and educational institutions should be productive and be able to build a better future and a strong nation for the young generation. Durkheim (1915, p.299)" as cited in (Brown \& Levinson ,1978) said that "the human personality is a sacred thing, one dare not violate it nor infringe its bounds, while at the same time the greatest good is in communion with others." Nowadays, because of the controlling and domination of the informatics and the virtual world, people prefer to communicate online, and each individual has a unique way or style to select the language variation, which can distinguish each person's identity. Herring (1996, p. 1) defines online communication as "communication that takes place between human beings via the instrumentality of computers."

Many types of online games like (PUBG) have appeared to be a vital tool of communication through which players express their anger using certain impolite expressions. Rahmayani (2018, p.373) points to the idea that people tend to utter

K C AL-KINDI CENTER

R D FOR RESEARCH ANI R D DEVELOPMENT Vour getewoy to warkd-clais research
Published by Al-KindiCenter for Research and Development. Copyright (c) the author(s). This is an open access article under CC BY license (https://creativecommons.org/licenses/by/4.0/) 
inappropriate expressions when in a difficult situation to express their anger and displease. These games have attracted the attention of many players especially the adolescents, through which they spend more than half a day interacting with other players. Players, consequently, use certain impolite and taboo expressions when they are angry. This can be considered verbal bullying which is definitely inappropriate and unacceptable. Therefore, it is important to know what is said, where, when, how, to whom, and why and to address the problems arising from this to modify the situations that require these expressions. Ehlich (1992, p. 2) and Jennings (2006, p.6) describe the necessity of investigating the field of impoliteness and violence to show the reasons behind using these expressions since it deals with the human behaviour and speech as a basis for building good relationships or otherwise.

The focus of this research is on the impolite expressions and bullying behavior produced by speakers and the reactionary expressions of the hearer. Holmes $(2013$, p.10) describes the various ways of speaking in various contexts and social conversations. Being more detail, to be impolite, critical and bully individual that needs an additional effort from the speaker to add much more expressions than the direct speech through any communication. Through these games there is a disaster for people who spend a lot of time doing nothing more than playing and imitate what the other said, so these impolite expressions will leave a bad impact on their language and makes a damage for the parents' desire to teach their kids how to be polite and socially acceptable. The major concern of this study is to focus on eliminating these expressions, realize their negative role, to cope with the hearer's reaction and the type of responses options during the beginning of this new trend of electronic interaction. Inevitably, what distinguishes this study is the idea that it is not based on the analysis of an individual's self-image only but goes far to recognize the kinds of face threatened as quality face, social identity face, relational face, equity rights, and association rights. Culpeper (as cited in Bousfield, 2008, p. 83) views impoliteness as a manner of speech through which the speaker intentionally or unintentionally uses certain expressions to attack the other interlocutors and cause disharmony and social disruption.

\section{2- Aims of the Study}

The study endeavors to clarify the idea that the researcher is not against playing these games at the spare time for enjoyment but against the idea of uttering impolite expressions other people and make them feel uncomfortable. So the present study aims at:

1. investigating whether these violent games particularly attract the players and encourage them to use impolite expressions, activating aggressive and violence responses among players. Moreover, who is the more likely effected via these violent games in the actual life.

2. investigating the reasons behind the spreading of offensive expressions purposely.

3. highlighting the negative influence of the impoliteness expressions used in these violence games on the players' real language Moreover, whether these expressions occur as a reaction to certain action or expressions.

4. Investigating whether there are any effects for the contextual variables such as (social status, age, gender and the impact of the other members) on the using of these expressions.

5.identifying the responses to these impoliteness and aggressive expressions and how it might make the addressee more depressed and anxious.

\section{Literature Review}

At the beginning the researcher tended to review every study dealing with the impoliteness in electronic games and their impact on the players' language and social behaviour. Actually, there are many studies that have dealt with the topic, but to the best of my knowledge, there is no English study about the impoliteness expressions in electronic games from sociopragmatic viewpoints. In a study done on pragmatics of impoliteness and rudeness, Mohammed and Abbas (2015) highlighted the main differences between the two expressions of impoliteness and rudeness to reveal which of them is intentional. They adapted Culpeper's (2005) strategies of impoliteness and Segarra's (2007) model of rudeness. They conclude that both of these two terms are interrelated and they have come up with the idea that impoliteness expressions can be occurring accidently and unintentionally as a reaction to certain behaviour, while rudeness expressions or behaviour is always occurring in intentional way.

Kecskes (2015), in his study on Intercultural impoliteness, argued that no act is inherently impolite because expressions and actions are surrounded by the context and speech situation. The results of the study revealed that these expressions or action may lose their value when they are uttered when the speaker himself may not be aware of strategies of politeness and impoliteness and these expressions appear without any attention or conveyed implicitly. 


\subsection{Violent online games}

Online games have become a significant part of kids' life. Gee (2003, p.5) and Moursund (2006, p.53) clarify that through gaming, kids can communicate with each other to have entertainment and enjoyment at the same time they learn and imitate more than other ways. Hakeeem and Abdulkhader $(2014$, p.12) state that playing is so useful to do entertaining activity and get an enjoyable time if it is designed to address a specific problem or to teach a certain skill . Wolf $(2012, p .7)$ defined a game as a "mental or body activities played".

Al-Shahrory and Remawy (2011, p.637) refer to the development of the phenomenon of playing and the game itself saying that children in the past spent most time playing outside in an open area but nowadays and according to the birth of many electronic and online games, the children's and adolescent's favourite hobby is to spend hours of day and nights. So, there is an important idea to shed the light on the electronic games and its types, investigate the most common expressions used among the players and measure the huge influence of these expression on the language use. So, for this reason, the researcher found that it is very necessary to investigate the role of these games on the player's language, their social behaviours and self-identity by entering the game with many players to collect the impoliteness expressions that accompanied these games and investigates to what extent the players became a lover of everything related to fighting, violence and bullying behavior.

Hogan and Strasburger (2018, p.5) declare that both young male and female youth are completely affected by other people's bad behaviour and imitate that to be their own style. Aguilera and Noguero $(2003, p .3)$ clarify the idea that young found the games as a matter of challenge and competition, through which they concentrate a lot to win and stay alive while they are playing, all that make the player behaves in such a way that reveals his intention to attack the other verbally and non-verbally

Muriel and Crawford (2018, p. 26- 30) state that there are many reasons behind the spreading of these games. These include the quality of these games and the fantastic design which makes people addicted to it. Also, Douglas, et al. $(2007$, p.22) argues that the lack of entertainment institution or alternatives project encourages the players to play these games despite of their negative impacts. Payne and Colewell $(2000$, p.22) refer to the role of violence games on the player's isolation from the others, which affects the social relations. Caillois (2001, p.5-8) concludes that playing is no matter than "an occasion of pure waste: waste of time, energy, skills, creativity, ingenuity and money". Bushman and Anderson (2001, p.354) and Gentile, et al. (2004, p.30) support Caillois's conclusions that violence tends to harm the participants and encourages on the principle of the criminal, violence behaviour and disrespect.

Dill (1998, p.410), who is interested in young health and behaviour, states that there is a great connection between the violent games and the player's behaviour in real world by killing and destroying the innocence of the kids by deceiving the players especially children to recognize that these bad things are ordinary and they can do whatever they want at any time.

\subsection{What is Impoliteness?}

It is difficult to study impoliteness without shedding light on the opposite field which is politeness. It is not surprising that politeness is an important field that occupies the attention of linguists. Verschuern $(1999$, p. 46) demonstrates that both of them have equal importance and function, so it is necessary to devote some attention toward these phenomena according to the urgent need for them in social conversation. Scovel $(1998$, p. 38) shows the necessity to deal with politeness and impoliteness from socio-pragmatic perspective to study the intended meaning of the speaker in any social communication since both of them depend from one side on the speaker's way of uttering these expressions, when, where and why, and how the listener receives and interprets it. Yule and Widdowson (1996, p.60), Eelen $(2001$, p. 1) and Olmen $(2017$, p.161) refer to politeness as the phenomenon through which a fantastic relation, respect, tact, harmony and unity occur between language and social interaction via using certain linguistic features with acceptable tones, discourse markers and particular principles. Olmen (ibid) noted that through the polite conversation, speakers tend to employ certain appropriate language to create and uphold interpersonal relationships. Actually, people in general have the desire to be socially acceptable and behave in a polite way to keep harmony and fulfill their social needs. Lakoff $(1990$, p. 34) highlights this idea by referring to the fact that to be a polite person means to select politer expressions and decrease the impolite one and avoid the abnormal behaviour, facilitating interaction by minimizing the potential for conflict and confrontation inherent in all human interchange. Thus, it is important to have a holistic vision for impoliteness. Culpeper et al. (2003, p. 1545) define impoliteness as "using language to cause an offence and attack the others verbally or non-verbally to cause a conflict and negative impact." 


\section{Reasons for Using Impolite Expressions}

Sometimes people are not shocked by impolite and taboo expressions as much as they are shocked by those who utter them. Cashman (2006, p.22) states that the absence of social bonds and jealousy with others, lack of family and school advices, without any deterrence from government authority, encourage practicing the use of impolite expressions.

Culpeper (2011, p. 23-25) states that impoliteness is a negative attitude towards specific behaviors occurring in specific contexts. Verschuern $(1999$, p. 46) argues that there is a need for some impolite expressions as a part of conversation for particular reasons, especially in online games. Hence, what are the reasons behind the use of these impolite expressions?

The first reason is truthiness. Culpeper (2011, p. 23) explains the fact that the speaker sometimes criticizes the hearer for such bad behaviours and justifies the impolite expressions and make it a matter of truthiness. Actually, the speaker wants to show disappointment and frustration to the listener to encourage the latter to improve and elicit the truth through investigation. Huang (2014, p. 152) maintains that a speaker intentionally tends to be innocent and tell the truth while he/she injures the other's feelings or would give signals that he/she is about to protect the addressee from other criticisms. Consequently, negative feelings and aggression might be created between them.

The second point is psychological aggression. The player is restless, tumultuous, carries the anger towards the other and has the desire to cause indignity and offence. Walther $(1992, \mathrm{p} .43)$ asserts that there is a negative impact for the number of hours through which players keep fighting online and doing nothing more than sitting and exclaiming impolite expressions towards those who defeated them. Culpeper $(2003$, p.838) identifies aggression as high degree in the impoliteness scale in that the speaker intentionally reflects tendencies to attack the others and express anger and frustration. Ibid $(2015$, p.9) adds that there is a great relation between the powerful speaker and the impolite expressions toward the less power one. Sameha $(2017$, p.11) states that violence is one of the most dangerous results of playing for a long time.

Thirdly, irony, entertainment and provocation of another's anger are also considered reasons for impolite expressions. Bernal $(2008$, p. 782$)$ refers to the idea that sometimes impolite expressions are used as a matter of amusement and to provoke another person. Cruse (2006, p. 132) defines these two terms, stating that the first one "allows us to be polite while being superficially rude," while the latter "allows us to be impolite while being superficially polite." These expressions are usually accompanied by a joke or slight laughter to incite humor.

The fourth reason refers to convergence and divergence. Bunz and Campbell $(2004, p .13)$ and Giles (1973), explained that the reason behind using impolite expressions and being discourteous include spoofing and imitation. They have no special opinion so they try to imitate the other's expressions and just to make fun of that person.

Orders and coercion can be considered the fifth reasons. Although they are functions of language, they carry impolite impression. The speaker in this case wants to affirm his/her assumed strong position, higher status, and power through impolite expressions (Brown \& Levinson ,1987, p. 65). Culpeper (1996, p. 350) clarifies that some expressions of order may sound impolite to others even if they are said politely. This does not mean that the speaker is impolite or does not know social conversation rules. Culpeper (2011, p.186-194) adds that when the order comes from a person who is in a higher social status, the hearer does not consider it impolite.

The crucial reasons are rudeness and mockery. Through these strategies, the speaker, hurt and harm others through impolite expressions. The speaker thinks that he/she is free to express opinions and judgments without taking into consideration the socio-pragmatic perspective. Rodina \& Workman $(2005$, p.3) point to rudeness as any verbal or non-verbal expressions that are intended to offend and hurt an addressee. Keinpointer (1997, p. 261) describes mockery as a way of cooperative and simulated rudeness. Bernal (2008, p. 782) describes it further as an impolite expression typically associated with laughter or joking.

Expression of anger and frustration. Beebe (1995, p. 154) and Anggita (2015, p.2) confirm that some people vent negative feelings and frustration by using strongly worded expressions andget power by using coercive impolite language. People usually these expressions to swear because they are the strongest way to express dissatisfaction.

In addition, some people utter these expressions to get the listeners' attention. This could be considered as an attempt to fix communication breakdown caused by the recipients' disinterest in the conversation. 
The last reason is that some individuals use the impolite expressions asa reaction to those who speak the same to them to defend themselves. When one exclaims impolite expressions to another, it is an expected consequence that the latter would retaliate and do the same, or the worse, to the former.

\section{Types of Reactions}

Albeit the fact that there are many researches on impoliteness, most of them tend to overlook the response to it. We are hardwired to have the desire to react to any action and interaction, verbally and non-verbally. An emotional response to impolite people is never helpful, but sometimes it is possible to meet someone make a deliberately offensive or provocative impolite expressions with the aim of upsetting the interlocutor or eliciting anger in him. Thus, Culpeper et al. (2003, p. 15623) classify people into groups. First is the offensive ones who directly intend to match or escalate conflict. The other one is the defensive people who prefer to ignore the attack non-verbally. There are those who accept the attack without any response $r$ verbally or non-verbally. Specifically, there are three types of reaction:

\subsection{Direct Response (Countering the attack)}

In some occasions people feel that they do not deserve these uncomfortable behaviours or criticisms, so they need to be offensive, react, and stop rude people. It may be essential to attack them and face them, especially if they do not care about the adverse effects of their rude expressions. Eventually, both the speaker and the listener attack each other with impolite and taboo words.

\subsection{Accepting the Attack}

Rude expressions or behaviour is usually a form of arousal. It can be assumed that those kinds of people understand that certain impolite expressions or behaviours occur. They then carry the responsibility for such expressions, instead of taking a defensive stance.

\section{3. Choosing Not to Respond}

Instead of being defensive or offensive, some people try to empathize with the others and understand the situation; they need to think because they are not accustomed to such impolite expressions or rude behaviour. Bousfield $(2008$, p. 188) clarifies that some people prefer to keep silent and not respond, since they recognize that dealing with such actions may be toxic. He adds that there are many reasons behind the listener's silence such as the disability to respond. Bernal $(1973$, p.66) points out that it might be due to the difficulty to understand the intended meaning of the expressions as well, hence the difficulty to handle the situation.

\section{Research Methods}

This research is descriptive and quantitative in nature. The data were collected from online games by participating in the game, particularly PlayerUnknown's Battlegrounds (PUBG), one of the widely played online games today. The researcher played the game with an English player to observe and record impolite expressions. Moreover, the researcher noted the responses as well as the reasons behind uttering these expressions. Two models, namely that of Culpeper (1996) and that of Spencer-Oatey (2002 \& 2005), were used to analyse the data.

\section{Model of Study}

Knowing the reasons behind using impoliteness strategies has been neglected and only very few studies have dealt with this issue. In determining such, Culpeper's (1996) and Spencer-Oatey's $(2005,2007)$ models were used.

\subsection{Culpeper's (1996) Model}

Bald on record impoliteness: In this strategy, the speaker intentionally, clearly and directly utters the impolite expressions to threat and attack the other's face since the speaker is in a more powerful situation than the other. The statement 'Stop speaking, we need to concentrate' said by a leader of the team to one of the members cannot be perceived as impolite. Bousfield (2008b, p. 132 describes that this is an unintentional attack toward the hearer.

Positive impoliteness: Huang (2014, p. 150) clarifies this type as surface realizations. In this strategy, the speaker tries intentionally to attack and damage the other's personality and exposes anger with negative emotion towards the other to achieve certain goal. Culpeper $(2005$, p.357) notices that the speaker tries as much as possible to ignore and snub the other, exclude, avoids the other, unconcerned, and use inappropriate identity markers, to make the other feel uncomfortable. 
Negative or coercive impoliteness: This type is frightening, condescending, scorning, or ridiculing. The speaker emphasizes his relatively powerful level than the target's level to ask about private and social information and prefer to annoy, harm the others freedom and indebtedness

Off-record impoliteness refers to sarcasm or mock impoliteness. The intended meaning of the speaker is completely opposite of what is said, so the speaker produces polite and acceptable expression to cover the impolite and inappropriate meaning. Mohammed and Abbas (2015, p. 199) call this as an ambiguous way of attacking and injuring the other.

\subsection{Spencer-Oatey's (2002, 2005) Model}

This model demonstrates the great and profound impact of impolite expressions.

Quality face: The speaker here tends to attack the interlocutor's physical appearance or the other's ability to do anything. Spencer-Oatey (2002, p. 540) refers to the people's desire to be acceptable in terms of our personal qualities."

Social identity and association face: Spencer-Oatey (2002, p. 540) discusses that the speaker here tends to scorn and ridicule the other's social ability, whereas the interlocutor wants to gain praise, or stick to his or her social identities or roles.

-Relational face: It refers to "the relationship between the participants (e.g. distance - closeness, equality-inequality, perceptions of role rights and obligations), and the ways in which this relationship is managed or negotiated" (Spencer-Oatey, 2007: 647).

-Equity face: Spencer-Oatey (2005, p. 100) describes that this strategy represents the role of the speaker when he tries to challenge the interlocutor, impose him, threaten, and block him physically or linguistically, on the other hand, what the interlocutor wants just to be treated fairly no more.

\section{Data Analysis}

1. "Oh, still bad playing". Just like you." The player here seems that he knows the other player and played with him earlier, so he wants to show his opinion about the other's awful way of playing by saying "bad". The speaker expresses in a disgusted tone that he is not satisfied with the other's playing, so the speaker wants to tell the truth and express his frustration and anger using negative and bald on record impoliteness to attack the quality face. On the other hand, the listener also keeps attacking the speaker directly as his reaction.

2. "Ya, animals, you are so funny. You are the animals". It is positive impoliteness, through which the speaker directly attacks the other player using the word 'animal' to show how stupid that player is and he likes the animal in the playing. The speaker attacks the listener's quality and relation face for two reasons: first is to be one of them (convergence) and to be ironic. At the same time, the listener as an ordinary reaction uses the same impolite expression to reply.

3. "Who cares how you play! Ok. Let's see, dummy". The first player criticizes the other one's way of fighting and claiming that no one cares about how he fights. It is negative impoliteness to attack the social and quality face of the other for three reasons: aggression, irony and rudeness. On the other side, the listener seems very confident of his ability to win.

4. "I am animal and bad players to play with you". The speakers here represent a strange situation that he criticizes and attack his own self's quality face and complains such a ridiculous occasion for two reasons: rudeness and expression of frustration or anger.

5. "Who are you? How dare you follow me. I am your master, idiot." The speaker here seems to mock the listener and make him feel inferior. The speaker uses negative impoliteness to attack the quality and equity face. There are three possible reasons behind using these expressions: aggression, irony and attention seeking. However, the listener prefers to respond directly.

6. "Your voice very nice ha ha, don't sing again". Another player expresses his opinion about the other player's voice and attacks him in a metaphorical way to express how disgusting the other sounds using off strategy. He mentions polite words to 
mean impoliteness and attack the quality and equity face for three reasons, the first one to tell the truth, mock and orders the other not to sing anymore because of the ugly voice. hence, the responder prefers to keep silent.

7. "We play with donkey. Aare you a donkey? You don't bother me". The speaker directly expresses his opinion and dissatisfaction with the other's skills with an angry tone, wondering in rhetorical way about such a kind of player. It is positive impoliteness where the speaker really wants to mock and show his frustration and anger and to attack the quality and relation face. In addition to that, the addressee directly presents his reaction.

8. "Show me yourself if you are a man." How dare dog. In the same context, the speaker attacks the hearer via threating him, since he dislikes that person, which shows resentment and hatred. So there is a use of positive impoliteness to attack the equity face of the hearer for many reasons Meanwhile, the addressee shows his frustration and directly attacks the speaker as well.

9. "Shit, you should run quicker. What! Watch your mouth." The player insults and attacks the other's way of playin using taboo words. It is negative impoliteness, which is used to attack the other's relation and equity face to show frustration and angry feeling. Moreover, the hearer demonstrates a direct reaction.

10. "Shut up f**ker. You shut up". The speaker here uses more abusive taboo word "fucker." It is positive impoliteness and there is an attack on quality and relation face. These words are used to order the listener not to speak at all and to express frustration and anger. As response, the listener repeats the same impolite word.

11. "My friend is a $\mathbf{n}^{* *} \mathbf{p}$." The speaker indicates in a sarcastic way to his friends in various ways that they are weak, which is obviously disrespectful and unsympathetic towards others. The speaker directly expresses his dislike and scorn towards the other player for being a $\mathrm{n}^{* *}$. There could be three reasons for this: truth, irony and rudeness. On the other hand, the listener prefers to accept these impolite expressions without saying anything.

12. "You are lying". The first player articulates his antipathy, anger and disgust towards such behavior. The speaker here is a girl talking in sarcastic way, showing her disgust and regret for such a player. It is positive impoliteness used to express the truth and frustration. There is no response from the others, which shows that it had a great effect on them.

13. "You are an asshole. Should have beien a doll. What about you, crazy man?" The player here is disgusted with what the other players did and attacks the other player's situation directly to suggest that it would be better if they have a doll instead of weapons The speaker uses more than two strategies of impoliteness. First, it is a bald on record impoliteness, positive impoliteness, and attack on the relation face. This is to show his rudeness, frustration and anger as well as to get attention. Consequently, the responders directly attack the speakers' expressions using impolite expressions.

14. "Hay an idiot. Yeah I am really idiot because I fight with such idiot like you." The speaker briefly declares that the other player is an idiot using an impolite word to show his disgust. It is a positive impoliteness. Moreover, the desire of the speaker to break the quality face is motivated by the intention to mock and get the attention. Ultimately, the girl directly replies with more hurtful and offensive words.

15. "I am a doctor. Doctor of what? Animals? ha ha" . In this statement, the speaker uses positive impoliteness to attack the social and quality face of the addressee. With sarcasm, the listener attacks the speaker directly.

16. "Shut up. I am not talking to you. F**k you." Spoofing, imitation and convergence can be the reasons behind this exchange. They have no special opinion so they try to imitate the other. The player here produces abusive expressions as appositive impoliteness to attack social face. In consequence, direct response comes to attack the speaker in an aggressive way.

17. "Ha-ha you scared me, womanish.F**k you." In a sarcastic way, the player expresses his opinion and criticizes the other player's behaviour to attack the other's social face. Actually, the use of the term ' womanish,' as positive impoliteness, can be considered more of an insult. The speaker produces this to show rudeness and irony. Meanwhile, the listener directly attacks the speaker with another taboo word. 
18. "What a $\mathbf{f}^{* *} \mathbf{k}$, you crazy man. $\mathrm{F}^{* *} \mathbf{k}$ you too". The speaker again shows aggression by calling the addressees names and repeteadlyusing insulting expressions because of $r$ their triviality and poor skills. The speaker uses negative impoliteness to attack and break their quality face. The addressee then gives a similar direct response.

19. "Are you crazy. Are you drunk? Yeah. You are so funny." The speaker seems unsympathetic towards the other player's attitude. The speaker here just wants to have fun without hurting him since he is one of the speaker's team members and can be considered a friend, so there is a type of relation between them. The speaker uses negative impoliteness to criticize the relation and quality face; hence the addressee directly responds with acceptance.

20. "so how old are you? Eleven. Eleven, what a heel. You are still young. Impossible; your voice seems that you are bigger. Hahaha, you stolid." This conversation seems a normal expression but it has sarcasm. The speaker softens the impolite expressions since the addressee is a girl and from the speaker's team. The speaker utters off impoliteness to attack the relation and social face to seek the truth and attention. The addressee prefers to responds directly with tough word and laughter.

21. "Hahaha. You can't hurt my dog". The speaker here expresses his disgust toward the listener's ability to fight. He mocks the other player's courage sarcastically and highlights the addressee's disability to defeat opponents. Hence, the speaker uses positive impoliteness to attack the addressee's social and quality. The addressee goes choosing not to respond.

22. "You can't use this, it's out of your stupidity." Again, in this conversation, the first player sarcastically attacks the other player and it is obvious that the speaker dislikes criticism of his bad playing by using an impolite word. This conversation occurs between friends in the same team. The speaker uses two strategies, negative impoliteness and bald on record impoliteness, to criticize the quality and relation face and express his frustration. There is no response from the addressee.

23. "Bullshit, how can you get weapons in this f**king game". Stop whining, you idiot." The speaker directly shows his disgust and scorn due to the difficulty acquiring weapons and associates it with taboo words ( $f^{* *} \mathrm{k}$ ). It is negative impoliteness used by the speaker to attack his quality face that he cannot get the weapons easily like the other players. He expresses his aggression and frustration, which shows convergence. Someone replied with harsh impolite words as a quick reaction to the speaker's expressions

24. "Go away; leave me alone." Speaking to a friend from his team, the speaker attacks the hearer and shows disrespect toward the addressee using order (bald on record impoliteness) to prove that he has authority over the addressee and can give them orders. /to show rudeness and frustration and to attack the equity face. Moreover, the addressee seems to understand the speaker's situation and leaves without any response.

25. "You are so beautiful dear but you are violent and deceitful. Yeah you are right." It is one word but it means a lot much. The speech contradicts itself, for a while, and the reader may think it is a polite utterance. However, if the statement is dissected, one can construe sarcasm. The speaker first was admiring of the addressee, but attacks her afterwards. Commendably, the speaker attempts to reduce the offence since he is addressing a lady. According to Culpeper's strategies, it is negative impoliteness used to attack the addressee's quality face for two reasons: to express an idea and to get attention. Consequently, the addressee implicitly agrees and accepts it. 
Tables (1) Frequency and Percentage of Impolite Expressions and Reactions based on Culpeper's (1996) and Spencer-Oatey's Models

\begin{tabular}{|c|c|c|c|c|c|c|c|c|}
\hline \multirow{2}{*}{$\begin{array}{l}\text { Types of } \\
\text { impolite } \\
\text { ness } \\
\text { expressio } \\
\text { ns }\end{array}$} & \multirow[t]{2}{*}{ Freq. } & \multirow[t]{2}{*}{ Perc. } & \multicolumn{3}{|c|}{ Reasons } & \multicolumn{3}{|l|}{ Responses } \\
\hline & & & \multirow[t]{2}{*}{$\begin{array}{l}\text { To say the } \\
\text { truth }\end{array}$} & Freq. & Per. & \multirow[t]{2}{*}{$\begin{array}{l}\text { direct } \\
\text { responses }\end{array}$} & fre. & Per. \\
\hline $\begin{array}{l}\text { Bald on } \\
\text { record } \\
\text { impolite } \\
\text { ness }\end{array}$ & 4 & $16 \%$ & & 9 & $36 \%$ & & 16 & $64 \%$ \\
\hline $\begin{array}{l}\text { Positive } \\
\text { impolite } \\
\text { ness }\end{array}$ & 11 & $44 \%$ & $\begin{array}{l}\text { To show } \\
\text { aggression }\end{array}$ & 6 & $24 \%$ & accepting & 5 & $20 \%$ \\
\hline $\begin{array}{l}\text { Negative } \\
\text { impolite } \\
\text { ness }\end{array}$ & 9 & $36 \%$ & $\begin{array}{l}\text { To scorn and } \\
\text { make fun }\end{array}$ & 10 & $40 \%$ & $\begin{array}{l}\text { choosing } \\
\text { not to } \\
\text { response }\end{array}$ & 4 & $16 \%$ \\
\hline $\begin{array}{l}\text { Withhold } \\
\text { politenes } \\
\text { s }\end{array}$ & 3 & $12 \%$ & $\begin{array}{l}\text { To express } \\
\text { convergence }\end{array}$ & 3 & $12 \%$ & & & \\
\hline $\begin{array}{l}\text { Spencer- } \\
\text { Oatey }\end{array}$ & & & $\begin{array}{l}\text { To express } \\
\text { order }\end{array}$ & 4 & $16 \%$ & & & \\
\hline $\begin{array}{l}\text { Quality } \\
\text { face }\end{array}$ & 16 & $64 \%$ & $\begin{array}{l}\text { Absence of } \\
\text { social morals } \\
\text { and rudeness }\end{array}$ & 9 & $36 \%$ & & & \\
\hline $\begin{array}{l}\text { Social } \\
\text { face }\end{array}$ & 7 & $28 \%$ & $\begin{array}{l}\text { To show } \\
\text { frustration } \\
\text { and anger }\end{array}$ & 10 & $40 \%$ & & & \\
\hline $\begin{array}{l}\text { Relation } \\
\text { face }\end{array}$ & 9 & $36 . \%$ & $\begin{array}{l}\text { To seek } \\
\text { attention }\end{array}$ & 6 & $24 \%$ & & & \\
\hline $\begin{array}{l}\text { Equity } \\
\text { face }\end{array}$ & 4 & $16 \%$ & & & & & & \\
\hline
\end{tabular}

\section{Results and Discussions}

It is worth mentioning that both of Culpeper's and Spencer-Oatey's models are applicable in the online game's and other contexts. Indeed, players deliberately utter impolite expressions to achieve certain aims. However, in these games, people tend to be rude and aggressive to express their frustrations, anger, and disgust toward others. It can also be noticed that these have effects on others, so they prefer to use and combine more than two impoliteness strategies. Absence of social bonds, rudeness, trolling to scorn the other, and get funny are the most dominant reasons found in online games. These are followed by stating ideas of judgments and expressing frustration and anger. Players prefer to avoid reacting toward impolite expressions when they belong the same team especially girls. This is shown by attempting to reduce the effect of impolite expressions in order to change the addressee's behaviour and encourage him/her to be better.

Generally, as indicated in the above table, the results of the research show that the number of strategies is more than the items since most of the players combine more than one strategy. Moreover, in terms of the types of strategies, the results prove that positive impoliteness is the most dominant type in which $44 \%$ was used by the players to to attack the others and to show violence and aggressive behaviour. The strategy with the lowest frequency (12\%) is withholding politeness, which still implies that violent online game creates aggressive and impolite participants. More complexity, impoliteness expressions, and reactions constitute a type of adjacency pairs; hence, most of them (64\%) use direct response by using the same bad expressions or add more than what is said. Moreover, only $16 \%$ of the players chose not to respond to impolite expressions, especially those who belong to the same team. Further, the results suggest that impolite expressions and behaviour are widely used in violent online games for some reasons such as to scorn others, make fun of them, and express frustration and anger, which records the highest percentage (40\%).Lastly, quality face takes $64 \%$ that shows that most players try as much as possible to damage their enemies' physical appearance. 


\section{Conclusions}

The huge use of impoliteness through these violence games exceeded the researcher's expectations. Based on the results of the study, the following conclusions are drawn:

1. While it might be hard to or it might be impossible to reject violent games, there is a necessity to raise cultural awareness and to limit the impact of these expressions on the player's language and behavior.

2. Young people in general and children in specific are more likely be effected by these phenomena through replying to each other via the intensive use of impolite expressions because leaving without responses might increase feeling of guilt, shame and burden.

3. Responses to speech that contain impolite cues were significantly more impolite.

4. There is a great influence for the contextual variants, situation, the degree of relationship between the players, gender, and so on.

5. Using these violent games to fight each other seems to temporarily increase the negative behaviour and leads to increase in the use of impolite language, aggressive responses and inherent anxiety.

6. Eventually, people differ from each other in terms of speech patterns which can emphasize their identity. Specifically, males in general have more sense of adventure and tendency to engage in impolite exchanges. 7. There are many reasons behind uttering impoliteness expressions. Some of them are quite unwieldy and unique while some appear to be a reaction to certain expressions or behaviour.

8. Eventually, at certain circumstances, some players tend to utter certain impolite expressions on themselves when they feel guilty or when they want just to punish themselves.

9. Females tend to utter less impolite expressions than male but there is no information on the variation between and among age brackets.

\section{References}

[1] De Aguilera, M., \& Mendiz, A. (2003). Video games and education: (Education in the Face of a "Parallel School"). Computers in Entertainment (CIE), 1(1), 1-10.

[2] AL-SHahrori,M. and AL-Rimawi,O.(2011) The Effect of Electronic Games on Memorizing, Problem Solving and Decision Making among Middle Childhood Jordanian Children. Studies journal. Jordanian. 38.2.p .649-637.

[3] Anderson, C. A., \& Bushman, B. J. (2001). Effects of violent video games on aggressive behavior, aggressive cognition, aggressive affect, physiological arousal, and prosocial behavior: A meta-analytic review of the scientific literature. Psychological science, 12(5), 353-359.

[4] Anggita, F. N. (2015). A Sociolinguistic Analysis of Taboo Words in Bad Teacher Movie. Undergraduated Thesis. Yogyakarta: Yogyakarta State University. Available on http://eprints. uny. ac. id/15998/1/Fika\% 20Nur\% 20Anggita\% 20102111440, 20.

[5] Beebe, L. M. (1995). Polite fictions: Instrumental rudeness as pragmatic competence. Georgetown University round table on languages and linguistics, 1995, 154J168.

[6] Bruner, J. S. (1973). Going beyond the information given. Beyond the information given, 143-175.

[7] Bernal, M. (2008). Do insults always insult? Genuine impoliteness versus non-genuine impoliteness in colloquial Spanish. Pragmatics, 18(4), 775-802.

[8] Bousfield, D. (2008). Impoliteness in interaction. Amsterdam: Benjamins.

[9] Brown, P and Levinson, S.C. (1987) Politeness. Cambridge University Press.

[10] Caillois,R. ( 2001). man, Play, and Games .University of Illinois press. Urbana and Chicago

[11] Cashman, H. R. (2006). Impoliteness in children's interactions in a Spanish/English bilingual community of practice. Journal of Politeness Research, 2(2), 217-246.

[12] Culpeper, J. (1996). Towards an anatomy of impoliteness. Journal of Pragmatics, 25, 349-67

[13] Culpeper, J., Bousfield, D., \& Wichmann, A. (2003). Impoliteness revisited: With special reference to dynamic and prosodic aspects. Journal of pragmatics, 35(10-11), 1545-1579.

[14] Culpeper, J. (2005). Impoliteness and entertainment in the television quiz show: The Weakest Link. Journal of Politeness Research, 1: 35- 72.

[15] Culpeper, J. (2011). Impoliteness: Using language to cause offence (Vol. 28). Cambridge University Press.

[16] Douglas, A.\& Gentile, K. \& Buckley, E. (2007). Violent Video Game Effects on Children and Adolescents: Theory, Research, and Public Policy. Oxford University Press.

[17] Ehlich, K. (1992). On the historicity of politeness. In R. Watts, \& S. Ide, K. Ehlich (Ed.), Politeness in Language. Studies in its History, Theory and Practice (pp. 71-107). Berlin: Mouton de Gruyter.

[18] GEE, J. P. ( 2003). What Video Games Have to Teach Us About Learning and Literacy. Palgrave Macmillan, New York

[19] Gentile, D. A., Lynch, P. J., Linder, J. R., \& Walsh, D. A. (2004). The effects of violent video game habits on adolescent hostility, aggressive behaviors, and school performance. Journal of adolescence, 27(1), 5-22.

[20] Hakeeem A. and Abdulkhader B. (2014). Video games and their impact on academic achievement and some sports activities among students teenagers. \{Master'stheses\},Warkala university press 
[21] Holmes, J. (2006) .Politeness Strategies as Linguistic Variables. In J. L. Mey (ed.) Concise Encyclopedia of Pragmatics (2 ed.). Oxford: Elsevier Ltd

[22] Herring,S. and stroerger,S. (1996). Gender and Anonymity in Computer-Mediated Communication. Handbook of Language and Gender. (2 ed). Hoboken, Wiley-Blackwell Publishing.

[23] Hogan, M., \& Strasburger, V. C. (2018). Social media and new technology: a primer. Clinical Pediatrics, 57(10), $1204-1215$.

[24] Huang, Y. (2014). Pragmatics. (2 ed.). Oxford, OXF: Oxford University Press.

[25] Kecskes, I.(2015). Intercultural impoliteness. Journal of Pragmatics. .86 p.43-47.

[26] Kienpointner, M. (1997). Varieties of rudeness: Types and functions of impolite utterances. Functions of language, 4(2), $251-287$.

[27] Lakoff, R. T. (1989). The limits of politeness: Therapeutic and courtroom discourse. Multilingua-Journal of Cross-Cultural and Interlanguage Communication, 8(2-3), 101-130.

[28] Mohammed, H. N., \& Abbas, N. F. (2015). Pragmatics of impoliteness and rudeness. American International Journal of Social Science, 4(6), 195-205.

[29] Moursund, D. G. (2006). Introduction to using games in education: A guide for teachers and parents. D. Moursund.

[30] Muriel, D. \& Crawford, G.(2018). Video Games as Culture: Considering the Role and Importance of Video Games. Routledge press.

[31] Olmen van D. (2017). Politeness Accommodation in Electronic MailUUa Bunz Scott W. CampbellRutgers University Hawaii Pacific University

[32] Olson, C. K., Kutner, L., Warner, D., Almerigi, J., Baer, L., Nicholi, A.. (2007). Factors correlated with violent video game use by adolescent boys and girls. Journal of Adolescent Health, 41, 77-83.

[33] Sameha ,B. (2017) Electronic games and school violence. \{Master'stheses\},.Baskara university press.

[34] Scovel, T. (1998). Psycholinguistics. China: Oxford University Press.

[35] Spencer-Oatey, H. (2005). (Im) Politeness, face and perceptions of rapport: unpackaging their bases and interrelationships. Journal of politeness research, 1(1), 95-119.

[36] Spencer-Oatey, Helen (2005) Rapport management: a framework for analysis. In H. Spencer-Oatey (Ed.), Culturally Speaking. Managing Rapport through Talk across Cultures. (pp. 11-46). London: Continuum.

[37] Vorderer,p. and Jennings B. (2006 ) Playing Video Games: Motives, Responses, and Consequences. Routledge. New York London

[38] Verschueren, Jef (1999). Understanding pragmatics. London: Arnold; New York: Oxford University press

[39] Walther, J. B. (2015). Social information processing theory (CMC). the international encyclopedia of interpersonal communication, 113.

[40] Wolf, M.J.P (2012). The Video Game Theory Reader. Routledge, London

[41] Yule, G. \& Widdowson ,H.G. (1996). Pragmatics. Oxford: Oxford University Press. 